\title{
PENGEMBANGAN SISTEM KOMUNIKASI AKADEMIK MENGUNAKAN METODE FOURTH GENERATION TECHNIQUE SEBAGAI SARA PERKULIAHAN MEMANFAATKAN TEKNOLOGI SMS GATEWAY
}

\author{
Rudiyan Syafutra. AZ *1, Wiwin Susanty ${ }^{{ }_{2}}$ \\ Program Studi Sistem Informasi \\ Fakultas Ilmu Komputer \\ Universitas Bandar Lampung \\ Telp. (0721) 701463, (0721)701979 Fax. (0721) 701467 Web. www.ubl.ac.id \\ Email..Wien_adetha28@yahoo.com \\ Handphone: 081272002552
}

\begin{abstract}
Perkembangan dunia komunikasi yang semakin meningkat dan kebutuhan informasi yang semakin meningkat memaksa orang untuk melakukan berbagai macam cara agar mendapatkan sebuah informasi yang cepat, tepat dan terbaru. Kesibukan dan mobilitas yang masyarakat yang tinggi membuat masyarakat tidak dapat melepaskan diri dari sebuah teknologi. Penggunaan telepon selular adalah salah satu bentuk pemecahan solusi dari sebuah informasi. Dengan adanya telepom selular seseorang akan mendapatkan informasi dengan cepat, tepat, dan terbaru.

Untuk itu penulis ingin mengembangkan sebuah sistem komunikasi yang akan memudahkan sesorang dalam mendapatkan sebuah informasi umumnya dilingkungan kampus Universitas Bandar Lampung, khususnya dilingkungan Fakultas Ilmu Komputer Universitas Bandar Lampung. Dengan memanfaatkan teknologi sms getway mahasiswa dan seluruh civitas akademik Fakultas Ilmu Komputer akan dapat menikmati sebuah layanan komunikasi akademik tanpa harus melihat jarak dan waktu antara pengguna dalam meakukan komunikasi.
\end{abstract}

Keywords : System Kumunikasi Akademik

\section{PENDAHULUAN}

\subsection{Latar Belakang}

Perkembangan teknologi dewasa ini semakin hari semakin meningkat. Tuntutan kerja, kesibukan dan mobilitas masyarakat yang tinggi membuat masyarakat tidak dapat melepaskan diri dari teknologi. Telepon selular adalah teknologi paling mutakhir yang dapat mengikis jarak dan waktu antara para pengguna dalam melakukan komunikasi. Dengan adanya telepon selular, tidak ada lagi penghalang yang berarti dalam melakukan komunikasi antara pengguna yang dipisahkan oleh jarak dan waktu. Dengan adanya hand phone membuat segalanya menjadi lebih mudah.

Pada teorinya, telepon selular adalah komunikasi bergerak berbasis suara dengan layanan tambahan berupa pesan singkat yang biasa dikenal dengan sebutan SMS (Short Message Service). Seiring dengan perkembangan zaman dan tingkat kebutuhan masyarakat terhadap privasi membuat SMS memiliki kedudukan yang menakjubkan. Fungsi SMS memiliki kesetaraan dengan penggunaan komunikasi bergerak berbasis suara. Ledakan yang dahsyat terhadap penggunaan SMS membuat para peneliti berdecak kagum. Hal ini membuat peneliti terus mengembangkan dan memaksimalkan fungsi SMS untuk memenuhi kebutuhan masyarakat.

Pada umumnya, SMS berfungsi untuk memberikan layanan pengiriman pesan singkat antar pengguna perangkat telepon selular. Dengan karakteristik seperti itu, pemanfaatan SMS menjadi sangat variatif, mulai dari harga pengiriman yang tetap, keamanan dan kesopanan, tidak mengganggu penerima dan handal (reliable) merupakan alasan. Selain itu, ada banyak alasan pengguna memilih komunikasi melalui SMS.

Berdasarkan alasan diatas, SMS memiliki peran yang begitu dominan sehingga SMS dapat dimanfaatkan sebagai perangkat yang berguna sebagai sarana informasi perkuliahan. Penggunaan 
sistem berbasis SMS di lingkungan kampus akan menguntungkan pihak-pihak yang berkepentingan. Sebagai contoh, sistem perkuliahan. Dengan adanya sistem ini mahasiswa dapat memperoleh informasi terbaru mengenai perkuliahan tanpa harus mengandalkan informasi dari teman. Kebutuhan mahasiswa terhadap informasi akan dengan mudah diperoleh melalui alat komunikasi telepon selular yang dimiliki masing-masing pengguna yang telah terdaftar sebagai member.

Informasi merupakan hal yang penting bagi mahasiswa terhadap perkembangan dunia kampus. Keterlambatan informasi membuat mahasiswa kehilangan banyak kesempatan. Pentingnya peran informasi menjadi inspirasi pengembangan sistem ini. Dengan memaanfaatkan tekhnologi SMS Gateway maka dikembangkanlah sistem yang digunakan sebagai sarana informasi perkuliahan. Agar mahasiswa dapat memperoleh Informasi perkuliahan mahasiswa tersebut harus terdaftar sebagai member dengan mendaftarkan diri melalui telepon selular sesuai format yang telah ditentukan. Informasi perkuliahan yang diterima mahasiswa itu berasal dari Dosen atau Staf Universitas Bandar Lampung yang telah terdaftar sebagai member.

Jika Dosen dan Staf Universitas Bandar Lampung telah menjadi member maka informasi yang mereka kirim ke sistem ini akan diteruskan kepada mahasiswa yang telah terdaftar sebagai member.

\subsection{Rumusan Masalah}

Pentingnya peran SMS sebagai media komunikasi bagi mahasiswa dan kebutuhan terhadap informasi perkuliahan menuntut peneliti untuk membuat sistem yang dapat menjembatani hubungan tersebut. Sistem berbasis SMS ini didesain dan dikembangkan dengan bahasa pemprograman $P H P$ dan database $M y S Q L$ serta tool pendukung lain sehingga dihasilkan prototype aplikasi yang handal dan user friendly.

\subsection{Batasan Masalah}

Batasan masalah pada sistem ini meliputi :

1) Sistem hanya akan meneruskan pesan teks (SMS) yang berasal dari Dosen dan Staf Universitas Bandar Lampung yang tercatat sebagai member dengan cara mengenali berdasarkan NIP dan password.

2) Sistem akan mengabaikan pesan masuk yang berupa pengumuman yang berasal dari mahasiswa.

3) Informasi yang sifatnya berupa pengumuman perkuliahan akan diteruskan kepada setiap member yang terdaftar sesuai dengan kebutuhannya masing-masing.

4) Setiap 1 (satu) nomor mobile phone hanya dimiliki oleh 1 (satu) member.

\section{$1.4 \quad$ Tujuan Penelitian}

Tujuan pembuatan sistem memanfaatkan teknologi SMS Gateway adalah :

1) Memberikan informasi mengenai kegiatan perkuliahan secara transparan kepada mahasiswa yang membutuhkan informasi dan tercatat sebagai member.

2) Membantu mahasiswa untuk memperoleh akses informasi terhadap perubahan jadwal perkuliahan sehingga mahasiswa tersebut memperoleh informasi yang bermanfaat dan tepat guna.

3) Meminimalisir jumlah mahasiswa yang tidak memperoleh informasi yang disebabkan oleh putusnya jaringan komunikasi oleh satu pihak yang tidak meneruskan akses informasi terhadap pergantian perkuliahan.

4) Memberikan kemudahan kepada mahasiswa yang ingin memperoleh informasi terbaru terhadap perkembangan dunia kampus.

\subsection{Manfaat}

1) Diharapkan dengan adanya sistem ini kebutuhan mahasiswa terhadap akses informasi terbaru mengenai perkembangan dunia kampus berupa pengumuman beasiswa, pergantian jadwal perkuliahan, pembukaan dan penutupan KRS dapat diinformasikan melalui SMS dengan memanfaatkan teknologi SMS Gateway.

2) Diharapkan dengan adanya sistem ini dapat memberikan manfaat terhadap pembelajaran bahasa pemprograman $P H P$.

3) Diharapkan kehadiran sistem ini dapat membantu mahasiswa memahami pentingnya ketepatan dan keakuratan sebuah informasi yang diperoleh sehingga informasi yang di dapat menjadi bermanfaat.

4) Diharapkan dengan adanya sistem ini mahasiswa dapat memahami fungsi SMS yang tidak hanya sebagai alat komunikasi personal akan tetapi memiliki fungsi alternatif sebagai sarana infomasi terhadap informasi perkuliahan.

\subsection{Kerangka Pemikiran}

Perancangan adalah suatu proses mendesain atau perbuatan yang menghasilkan rancangan. Sistem Komunikasi Akademik adalah sebuah sistem yang berisikan informasi-informasi yang berkaitan 
dengan kegiatan akademik mahasiswa, seperti Jadwal mata kuliah, KHS, KRS, Dll.

Adapun sasaran yang dituju dari Sistem Komunikasi Akademik ini adalah Mahasiswa Yang Menempuh Perkuliahan dan para civitas akademik pada Fakultas Ilmu Komputer Universitas Bandar Lampung yang dijadikan objek dalam penelitian ini.

Metode fourth generation tehnique adalah salah satu metode yang cocok digunakan untuk melakukan pengembangan perangkat lunak. Istilah Fourth Generation Technique (4GT) meliputi seperangkat peralatan Software yang memungkinkan seorang developer Software menerapkan beberapa karakteristik Software pada tingkat yang tinggi, yang kemudian menghasilkan source code dan object code secara otomatis sesuai dengan spesifikasi yang ditentukan developer.

SMS Gateway adalah sebuah aplikasi Short Massage Service (SMS) yang dapat di jalankan melalui Local Area Network (LAN), aplikasi ini dapat digunakan bersama-sama dalam satu jaringan.

PHP (Profesional Home Page) adalah bahasa scripting yang menyatu dengan HTML dan dijalankan pada Server Side yang akan diakses dalam server side.

\section{METODOLOGI PENELITIAN}

\subsection{Peralatan dan tools}

Kebutuhan minimal Hardware: Intel Pentium II PC dapat berbentuk Desktop/Server maupun Notebook, Memory 64 Mbyte, Harddisk dengan ruang kosong 300 Mbyte (diluar sistem operasi), Infrared, Kabel data serial/USB untuk telepon seluler/GSM. Modem Telepon seluler/GSM Modem Nokia/Siemens Kartu GSM Prabayar/paska bayar Network Card (optional) untuk menjalankan SMS gateway dari jaringan Koneksi Internet (optional) menjalankan SMS gateway dari Internet

\subsection{Kebutuhan Software Penunjang}

Sistem Operasi Microsoft Windows XP MS Windows XP/2003 Database MySQL for Windows Apache Web Server for Windows PHP for Windows Gammu

\subsection{Metode Eksperimen}

Penelitian ini dilakukan dengan pengujian apakah sesuatu objek penelitian sesuai (cocok) dengan kondisi tertentu yang telah terjadi atau sesuai dengan syarat-syarat tertentu. Penelitian dilakukan karena sesuai dengan kebutuhan informasi mahasiswa terhadap perkembangan informasi yang ada di Universitas Bandar Lampung. Dengan tuntutan informasi yang semakin meningkat, peneliti dituntut untuk melakukan sebuah observasi eksperimen dengan membuat sebuah sistem yang akan memenuhi kebutuhan informasi mahasiswa.

Berikut ini adalah langkah penelitian perancangan perangkat lunak :

1) Mempelajari teori - teori yang berkaitan dengan perancangan perangkat lunak meliputi kesesuaian metode yang digunakan, koneksi gammu dengan SMS gateway, fungsi dan manfaat sms, serta tujuan adanya pengumuman mengenai kegiatan perkuliahan di lingkungan kampus.

2) Mempelajari metode perancangan perangkat lunak. Metode ini terdiri dari serangkaian tugas :

a) Perencanaan \& estimasi proyek

b) Identifikasi kebutuhan sistem meliputi : software, harware, struktur dataDesain struktur data. Arsitektur program dan prosedur algoritma, Coding, Testing, Deployment dan pemeliharaan

c) Menyiapkan peralatan (tools) yang digunakan pada perancangan perangkat lunak

d) Mempelajari procedure atau langkah langkah perancangan perangkat lunak

e) Pengembangan sistem

f) Deployment dan maintenance

g) Identifikasi kebutuhan sistem yang meliputi harware, software, data struktur data

\section{KESIMPULAN}

Berdasarkan pembahasan diatas dapat disimpulkan bahwa :

1) Sistem komunikasi ini dikembangkan untuk menjebatani komunikasi antar mahasiswa dan dosen tanpa dibatasi oleh jarak dan waktu. Informasi yang disampaikan oleh dosen akan sampai ke member mahasiswa tepat waktu dan sesuai dengan kebutuhan masing-masing mahasiswa. Dosen tidak perlu menyebarkan informasi dengan menempel pengumuman pada papan pengumuman. Hal ini dilakukan untuk meminimalisir mahasiswa yang tidak datang ke kampus dan tidak memperoleh informasi dari teman. Dengan adanya sistem komunikasi ini mahasiswa dapat menerima informasi dan mengetahui informasi terbaru tanpa harus datang ke kampus.

2) Sistem ini dikembangkan dengan memanfaatkan teknologi SMS gateway yang dihubungkan oleh perangkat komputer yang dikoneksikan dengan telepon selular dan di-handle oleh jaringan 
selular untuk menghasilkan informasi yang tepat guna.

3) Sistem ini dikembangkan menggunakan metode fourth generation technique sebagai metode pengembangan sistem untuk menghasil perangkat lunak yang berkualitas, efektif dan efisien.

4) Mahasiswa yang tercatat sebagai member dapat memperoleh informasi nilai yang berupa indeks prestasi, beasiswa serta pengumuman lain yang berkaitan dengan kegiatan perkuliahan dalam bentuk SMS.

\section{SARAN}

Sistem komunikasi masih jauh dari kesempurnaan. Dibutuhkan partisipasi aktif dari pembaca untuk mengembangkan sistem ini agar menjadi sistem yang lebih baik dari segi kualitas dan kuantitas.

Diharapkan sistem ini dapat menyediakan fasilitas untuk melakukan pengisian KRS dan dapat melihat indek prestasi kumulatif mahasiswa melalui fasilitas SMS yang ada pada telepon selular.

Sistem ini dibuat untuk memberikan layanan kemudahan bagi mahasiswa yang memiliki mobilitas tinggi terhadap waktu. Dengan hanya mengirim SMS maka mahasiswa tersebut akan memperoleh informasi sehingga dapat menghemat waktu. Dengan adanya sistem yang dikembangkan melalui fasilitas
SMS diharapkan dapat mengikis jarak dan waktu yang membatasi hubungan antara mahasiswa dan dosen.

\section{REFRENSI}

1) http://www.edusoft.web.id/index.php?option=co $\mathrm{m} \_$content\&task=view\&id=17\&Itemid=37. tanggal 13 Jan 2009 18:21:10 (diakses dari gus_dwix_adjust@yahoo.co.id tanggal 19 maret 2009)

http://www.total.or.id/info.php?kk=technique http://weleh99.multiply.com/journal http://books.google.co.id/books?id=vLFiZwW8 gK0C\&pg=PA9\&lpg=PA9\&dq=tool+fourth+ge neration+technique \&source $=$ bl\&ots $=\mathrm{zWd} 9$ okkS Et\&sig=k3nRdKeuhbgZsEnSPfunAIOttHM\&hl $=i d \&$ ei $=$ eywNStCRGNKHkAWXmrSrBA\&sa $=$ $X \&$ oi=book_result\&ct=result\&resnum=1\#PPA1 2,M1

(www.php.net), (www.apache.org), (www.microsoft.com), (www.mysql.com), (www.gammu.org)

2) Zakaria, Teddy Marcus dan Widiadhi, Josef. 2006. Aplikasi SMS untuk berbagai keperluan. Informatika. Bandung www.ilmukomputer.com (oleh : Muhadkly (Acho) email : acho@muhadkly.net Hakim, lukmanul, 2008. membongkar trik rahasia para master php. Lokomedia. Yogyakarta 